Brit. J. vener. Dis. (1959), 35, 264.

\title{
TREATMENT OF NON-GONOCOCCAL URETHRITIS WITH TRI-ACETYL-OLEANDOMYCIN*†
}

\author{
BY \\ R. R. WILLCOX \\ St. Mary's Hospital, London
}

The number of male cases of non-gonococcal urethritis (NGU) treated in the clinics of England and Wales continues to rise steadily each year, and have done so ever since figures were first published in 1951. The cause of the condition remains undiscovered and a variety of antibiotics, including the tetracyclines, spiramycin, erythromycin, and streptomycin (in conjunction with sulphonamides), may be used in its treatment. The present paper concerns the use of tri-acetyl-oleandomycin $\dagger$ capsules, each containing tri-acetyl-oleandomycin equivalent to $250 \mathrm{mg}$. oleandomycin base. One hundred male patients with uncomplicated NGU were each given one 250-mg. capsule four times daily for 6 days (total 6 g.).

\section{Material}

Race.-Of the 100 patients, thirty were Negroes (28 from the West Indies and two from West Africa). Of the remainder, 53 were from the United Kingdom, six from Eire, three from the U.S.A., two from Spain, and one each from Cyprus, Hungary, New Zealand, Pakistan, Poland, and Yugoslavia.

Age.-The average age was 29.5 yrs (range 17 to 50 yrs), being $27 \cdot 2$ yrs for the Negroes and $30 \cdot 5$ yrs for the remainder.

Marital Status.-68 patients were single, 31 were married, and one was separated from his wife.

Previous Venereal Disease.-32 patients (only three Negroes) had had no previous venereal incident. The remainder had experienced 110 previous attacks of gonorrhoea, 72 of NGU, three of syphilis, three of venereophobia, two of non-specific penile sore, and one each of soft sore, condylomata acuminata, scabies, and epididymitis. In spite of their lower average age,

\footnotetext{
* Received for publication October 1, 1959.

t "Evramycin" (Wyeth).
}

the thirty Negro patients accounted for 103 of these 194 previous incidents (average 3.4 each compared with an average of 1.3 each for the remainder).

Duration of Disease.-The discharge had been present before treatment for 1-3 days in 47 cases, 4-7 days in $31,8-14$ days in nine, 15-21 days in three, 22-28 days in five, and longer than this in five cases. 54 patients complained of some dysuria and 46 did not.

Source of Infection.-The disease was apparently contracted from a stranger in 49 cases, from a friend in 39 , from the wife in ten, and from a male person in one; In one case the source was unknown.

Apparent Incubation Period.-1-3 days in nineteen cases, 4-7 days in 22, 8-14 days in nineteen, 15-21 days in ten, 22-28 days in four, and over 28 days in seventeen cases. In nine cases the incubation period was not known.

Serology.-The routine Wassermann reaction (W.R.) and VDRL (or Kahn) tests were both negative before treatment in 91 cases. In nine patients, the W.R. was negative and the VDRL test was positive; six of these were Negroes and the low-grade seropositivity was probably due to past yaws in some instances. The gonococcal complement-fixation test was done in 83 cases, and the result was negative in 79, doubtful in one, and positive in three patients, two of whom were West Indians.

\section{Case Management}

In all cases gonococci were excluded by Gramstained urethral smear before treatment and routine serological tests for syphilis were carried out. One tri-acetyl-oleandomycin capsule was prescribed four times daily for 6 days, and the plan was to see patients at $1,2,4,8$, and 12 weeks from the start of therapy.

At each visit the urethral meatus was examined for discharge (a smear being taken if one was present) and the urine was examined for haze and threads. It was intended to examine the prostatic secretion at least twice during surveillance and to make final 
TABLE I

RESULTS IN 100 MALE CASES OF UNCOMPLICATED NGU TREATED WITH $6 \mathrm{~g}$. TRI-ACETYL-OLEANDOMYCIN

\begin{tabular}{|c|c|c|c|c|c|}
\hline \multirow{2}{*}{$\begin{array}{l}\text { Length of } \\
\text { Follow-up }\end{array}$} & \multirow{2}{*}{$\begin{array}{c}\text { No. } \\
\text { Followed }\end{array}$} & \multicolumn{4}{|c|}{ Result } \\
\hline & & $\begin{array}{l}\text { Satis- } \\
\text { factory }\end{array}$ & Failure & $\begin{array}{c}\text { Re- } \\
\text { infection }\end{array}$ & $\begin{array}{c}\text { Gonococcal } \\
\text { Infection }\end{array}$ \\
\hline $\begin{array}{r}1-7 \text { days } \\
8-14 \text { days } \\
15-21 \text { days } \\
22-28 \text { days } \\
1-2 \text { mths } \\
2-3 \text { mths } \\
\text { Over } 3 \text { mths }\end{array}$ & $\begin{array}{l}85 \\
77 \\
63 \\
53 \\
47 \\
30 \\
14\end{array}$ & $\begin{array}{r}5 \\
7 \\
4 \\
4 \\
13 \\
10 \\
10\end{array}$ & $\begin{array}{l}3 \\
5 \\
5 \\
2 \\
2 \\
2 \\
-\end{array}$ & $\frac{\overline{1}}{-}$ & $\begin{array}{r}-1 \\
1 \\
- \\
1 \\
2 \\
1\end{array}$ \\
\hline
\end{tabular}

serological tests for syphilis after 3 months. Not all patients, however, attended as instructed.

Surveillance was deemed complete after 3 months of observation if a satisfactory status had been maintained throughout, a recurrence had required re-treatment, or an intercurrent gonococcal infection had been incurred. No attempt was made to distinguish relapse from re-infection except that all recurrences after 3 months were classified as reinfections.

\section{Results}

In the cases in which treatment was successful the response was immediate. Side-effects were few: only three white patients complained of rectal burning, soreness, or írritation.

The follow-up and results are shewn in Table I, and Table II compares the results in the two racial groups.

Seven of thirty Negroes $(23 \cdot 3$ per cent.) and only seven of seventy non-Negroes (10 per cent.) failed to return for observation. There was also a higher incidence of intercurrent gonococcal infection and of recurrence of non-gonococcal infection, believed to be due to re-infection, in the Negro group. Notwithstanding, the overall difference in the re-
TABLE II

COMPARISON OF UNSATISFACTORY RESULTS IN NEGROES AND NON-NEGROES

\begin{tabular}{c|c|c|c|c|c|c|c}
\hline \multirow{2}{*}{ Race } & \multirow{2}{*}{$\begin{array}{c}\text { No. } \\
\text { Treated }\end{array}$} & $\begin{array}{c}\text { No. } \\
\text { Followed }\end{array}$ & $\begin{array}{c}\text { Gono- } \\
\text { coccal } \\
\text { In- } \\
\text { fection }\end{array}$ & $\begin{array}{c}\text { Fail- } \\
\text { ure }\end{array}$ & $\begin{array}{c}\text { Re-in- } \\
\text { fection }\end{array}$ & $\begin{array}{c}\text { Re- } \\
\text { treatment } \\
\text { Rate }\end{array}$ \\
\hline $\begin{array}{c}\text { Negroes } \\
\text { Nert. }\end{array}$ & 30 & 22 & 74 & 3 & 5 & 2 & $31 \cdot 8$ \\
\hline $\begin{array}{c}\text { Non- } \\
\text { Negroes }\end{array}$ & 70 & 63 & 90 & 2 & 14 & 2 & $25 \cdot 4$ \\
\hline Total.. & 100 & 85 & 85 & 5 & 19 & 4 & $27 \cdot 1$ \\
\hline
\end{tabular}

treatment rate was small enough to justify considering both groups together.

\section{Summary and Conclusions}

(1) One hundred males with uncomplicated NGU were treated with $6 \mathrm{~g}$. tri-acetyl-oleandomycin orally in 6 days.

(2) Of 85 patients followed, $23(27 \cdot 1$ per cent.) were re-treated for NGU within 3 months. No attempt has been made to distinguish relapse from re-infection although reinfection was suspected in four of these cases. Further infection with gonorrhoea occurred within 3 months in five cases.

(3) Side-effects were few. Rectal soreness, irritation, or burning was noted by three patients.

(4) The success rate $(72.9$ per cent.) indicates that in tri-acetyl-oleandomycin venereologists have another antibiotic for nongonococcal urethritis.

Thanks are expressed to John Wyeth and Brother Ltd. for supplying the "Evramycin" used in this study. 